\title{
TOURIST FLOWS BETWEEN CENTRAL EUROPEAN METROPOLISES (IN THE CONTEXT OF METROPOLISATION PROCESSES)
}

\author{
Martin ŠAUER ${ }^{1}$, Markéta BOBKOVÁ ${ }^{1}$
}

DOI: $10.21163 / G T \_2018.132 .10$

\begin{abstract}
:
This paper focuses on the tourist flows between Central European metropolises. The main aim is to identify these flows and to evaluate position of metropolises within the spatial structure of the Central European tourism. The core of the analysis lies in the evaluation of the main tourist flows and their spatial distribution. Hence, the paper measures the appropriate quantitative network characteristics of tourist flows and visualizes them. For this purpose, it is also necessary to find a method that allows quantifying tourist flows, because current statistics cannot capture tourist streams at the level of individual metropolises. Finally, the results are discussed in the context of metropolisation processes. The results reveal the importance of the Vienna network connection, as the most important analysed tourist destination, to the rest of the metropolises. The weakness of the network connection has been confirmed especially in Polish metropolises, while Berlin can be considered an important transit hub.
\end{abstract}

Key-words: urban tourism, tourist flows, network analysis, metropolis, Central Europe

\section{INTRODUCTION}

Nowadays, tourism is a global branch of the world economy. Just international tourism's share of the global GDP amounts to $10 \%$ and makes up about $7 \%$ of the global export. In this context, tourism ranks third among the most significant export industries in the world (UNWTO, 2017). Trips to cities represent quite significant part of the global tourism. Urban tourism is considered by United Nations World Tourism Organisation (UNWTO) to be an important segment of the international tourism, and as such, it plays a significant role in economic as well as in social environment of many urban destinations. According to World Travel Monitor (IPK International, 2015), Trips to cities make up about $22 \%$ of all holiday flows; moreover, between 2007 and 2014 the number of such trips went up by $82 \%$. Obviously, the importance of urban tourism is reflected also in the role of tourism within urban economy (e.g., Dumbrovská \& Fialová, 2014). Development of urban tourism in cities can also be a driving force of their economic, social and spatial transformation, which is projected for instance in revitalisation of public spaces, development of public infrastructure, interconnection of residential and recreational functions of the cities, enterprise enhancement and development of partnership between public and private sectors, or attracting other trade industries and services (UNWTO, 2018).

In addition, we can witness urbanisation processes which are probably, on a long-term basis, most visible outcomes of the global socio-economic development (Viturka et al., 2017). These days, more than $50 \%$ of the world population live in cities and make up more than $60 \%$ of the global GDP. By 2030, the share of city population will increase to about $66 \%$, whereas this number will double in developing countries, and the built-up area could

\footnotetext{
${ }^{1}$ Masaryk University, Faculty of Economics and Administration, 60200 Brno, Czech Republic, martin.sauer@econ.muni.cz; marketa.bobkova@econ.muni.cz.
} 
be even three times larger (UN-Habitat, 2015). That implies that metropolisation may be considered as a higher stage of urbanisation, which is no longer primarily focused on the concentration of population, but on the concentration of importance. On one hand, the source of importance comes from the concentration of production services, finance, technologies, trade and people in one place, which creates space for the economies of scale and for creation of synergies. In this context, we can talk about agglomeration effects which influence, through labour mobility, also the background of metropolises (Pařil et al., 2015). On the other hand, interconnection of metropolises is an even more significant factor which stimulates horizontal and vertical cooperation of metropolises as an important tool for enhancement of national and regional competitiveness (Viturka et al., 2017). Metropolises functioning within networks have stronger ties with one another than with the surrounding hinterland (Jałowiecki, 2006). Additionally, there does not exist just one global network of metropolises, but on the contrary, the networks are internally specialised and hierarchically arranged (Castells, 2008). It corresponds also to the assumption (for more information see Viturka et al., 2017) claiming that human advance is characteristic due to hierarchic differentiation of social systems and their integration through spatial division of labour. Furthermore, Viturka et al. (2017) state: "The resulting spatial arrangement ensures coherence of social systems reflecting the achieved level of balance between economic, social and ecological factors. As for the spatial integration of the systems, the following driving forces are considered to be decisive: labour interactions on a microregional level, production interactions on a mesoregional level, administrative interactions on a macroregional level and trade interactions on a global level."

Beyond doubt, the international tourism contributes to such processes. It enhances connection to global space systems both on a transport level and a trade level (congress and trade fair tourism), or a socio-culture level (creative industries, attractiveness of the city, culture and social life).

Contemporary literature dealing with tourist mobility is particularly extensive (Ferrante, Abbruzzo, \& De Cantis, 2017). Travel routes analysis dominates over publication outcomes; at least five studies analysing tourist flows in various localities have come into existence in the course of the last quarter century (Mings \& McHugh, 1992; Lue, Crompton, \& Fesenmaier, 1993; Flognfeldt, 1999; Lew \& McKercher, 2002). In total, 26 various types of travel itineraries were identified, distinguished according to the way of transport, distance, number of stops and in-land and cross-border journeys. Subsequently, McKercher and Lew (2004) came to create four fundamental patterns of visitors' mobility: The simplest itinerary style involves a single main destination, there and back journey with or without a side trip. The second itinerary style includes a journey to a main destination, out of which the visitor sets out for a round tour while staying overnight in various places. After the round tour is completed, the tourist comes back to his/her original destination and via the same journey he/she leaves the destination. The third type of journey is just a round tour with multiple stops, there is no transit to the main destination. The last style of travelling is a hub-and-spoke, which means that tourists come to a main destination and make individual (one-day or more-days) trips always returning back to the original destination. Thus, the spatial structures of the tourist flows analysis is based on the application of the network analysis methods (D'Agata, Gozzo, \& Tomaselli, 2013; Lee et al., 2013; Luo, MacEachren, 2014; Hong, Ma, \& Huan, 2015) and the methods of sequence alignment (Shoval \& Isaacson, 2007; McKercher, Shoval, Ng, \& Birenboim, 2012). There are also studies coming to light that simulate tourist flows through gravity approaches (Khadaroo \& Seetanah, 2008). 
The aim of this paper is to identify ties between Central European metropolises, and based on this identification to evaluate position of individual centres within the network. Taking into consideration the data availability, the fundamental task of this paper is to find a method which makes the quantification of tourist flows between individual centres possible. The contemporary statistics is not able to capture tourist flows at the level of individual cities. Therefore, it is necessary to find a method which will be able to estimate such flows.

\section{METHODOLOGY AND DATA}

The fundamental file consisting of 27 analysed metropolises has been taken over from the article The Metropolisation Processes - A Case of Central Europe and the Czech Republic (for more information see Viturka et al., 2017). Selection of the metropolises is based on three qualitative and quantitative components: the population of the metropolis, a sufficient size of which is regarded to be an initial assumption for commencement of the metropolisation process, the economic profile emphasising representation of knowledgebased industries, and finally, the investment attractiveness reflecting high quality of entrepreneurial and social environment. The Central European region includes Germany, Switzerland, Austria, Poland, the Czech Republic, Slovakia, Hungary, and Slovenia.

Intensity of tourist flows is spatially determined by attractiveness of destinations, population size of source centres and distance between the centres. Modelling of tourist flows is based on the information on proved demand for the studied metropolises and identification of sources of such demand by means of a gravity model. We obtained an overview on geographic structure of metropolises' attendance in 2015 from TourMIS (see Wöber, 2003) database, or alternatively from the national statistical offices. The data is available according to individual source countries. Therefore, it was necessary to estimate a share of tourist arrivals which will be attributed to studied metropolises in each country. At first, based on a share of the number of inhabitants of all metropolises on the number of inhabitants of a given state we estimated the tourist arrivals to all metropolises in the particular country. Next step was an estimation of the tourist arrivals contributed to individual metropolises. We used a gravity model which estimates capacity of interactions under conditions of insufficient availability of the data:

$$
\mathrm{G}_{\mathrm{ij}}=\frac{\mathrm{m}_{\mathrm{i}} \times \mathrm{m}_{\mathrm{j}}}{\mathrm{d}_{\mathrm{ij}}},
$$

whereas $\mathrm{G}_{\mathrm{ij}}=$ economic force acting between metropolises, $\mathrm{m}_{\mathrm{i}}=$ overall foreign attendance of a metropolis, $\mathrm{m}_{\mathrm{j}}=$ number of inhabitants living in the source metropolis, and $\mathrm{d}_{\mathrm{ij}}=$ distance between the involved metropolises.

To measure the distance, we considered the length of the fastest highway/motorway connection (taking into consideration the maximum daily driving limits for trucks according to the EU Regulation which correspond to a maximum distance of $600-700$ kilometres). As a result, we got a set of tourist flows for each pair of studied metropolises (origin-destination matrix).

With the aim to map the structures of the identified tourist flows and to evaluate the integration capacity of the Central European metropolises we applied the network analysis method. The outputs are created in Gephi 0.9.2, by means of which various types of networks are modelled. Gephi has its own data laboratory with an Excel-like interface to 
manipulate the data columns, search and transform the data (Bastian et al., 2009). After selection of desired criteria, the program can adjust the size and colour of nodes so as the appearance of the network could be visualised from various perspectives. By using the module which divides the network nodes into positions according to latitude and longitude, it is easy to link the network analysis also with a spatial perspective (e.g. Luo, MacEachren, 2014; Bobková, Holešinská, 2017). Moreover, Gephi offers variety of other advanced visualisation technologies for which it uses various algorithms influencing the arrangement of nodes and network shapes, which allows easy understanding of identification of critical points and opportunities in the studied structures.

Specific algorithm in Gephi software, which offers a simplified view on a certain part of reality, proved to be a suitable tool for modelling. By means of modelling, the studied phenomena can be better understood, and behaviour of such systems can be found out by observation. However, to get a plausible depiction of a model, the target needs to be specified beforehand and quality data background must be prepared.

The assessment of ties and structures is based on the number of network matrices. The key ones deal mainly with centrality which is most frequently used for identification of key positions. The centrality analysis makes comparison of the structure and functioning of various networks possible. The centrality represents placement of nodes within the network. The nodes can be clustered within the network according to their degree. They are expressed by the number of links between individual stakeholders (Hanneman \& Riddle, 2005). In our case, a degree of centrality can be distinguished into in-degree (thus, the links ending at a given node; input) and out-degree (the links starting at a given node; output). Based on the in-degree value it is possible to identify the so-called hubs within the network.

Centrality does not have to be assessed just according to a degree. It is also possible to use, for instance, the so-called closeness centrality, which means that the node is in the centre of affairs and it has a favourable position to be linked with other nodes. The nodes with the highest level of closeness centrality have, in a figurative sense, the best overview of what is happening within the network (Hanneman \& Riddle, 2005).

Another centrality is represented by the so-called betweenness centrality. The nodes with high betweenness centrality are regarded to be intermediaries since they link the clusters and have a favourable position for control of information spread; although, the number of their edges within the network does not have to be of great importance. They generate opportunities for innovations and growth in the network because they have, thanks to their proximity to other clusters, access to different perspectives and ideas unknown to other network nodes (Hoppe \& Reinelt, 2010).

\section{RESULTS AND DISCUSSION}

According to statistical offices in relevant countries, accommodation in all studied countries was provided to 40.5 million foreign tourists in 2015. However, attendance of metropolises is significantly spatially differentiated. Determinant deviation of attendance is higher than the average value for the whole set of metropolises. More than half of the cities do not reach the boundary of 1 million foreign visitors per year. Fig. 1 demonstrates a set of metropolises which have entered the analysis and their categorisation with respect to their tourist importance. Such importance was determined on the basis of layout of their overall foreign attendance by using Jenks natural breaks classification method. The global importance category includes only three metropolises: Prague (5.7 mil.), Vienna (5.5 mil.) and Berlin (4.9 mil.). Those cities generate almost $40 \%$ of the entire attendance. The second 
most important group is created by three German metropolitan regions of Rhein-Ruhr, Frankfurt am Main, Munich, and also Budapest, Hungary. The third group includes most popular Polish cities of Warsaw and Krakow, and German metropolises of Hamburg and Mannheim, and Zurich, Switzerland. Position of the other metropolises in respect to tourism is not of great importance.

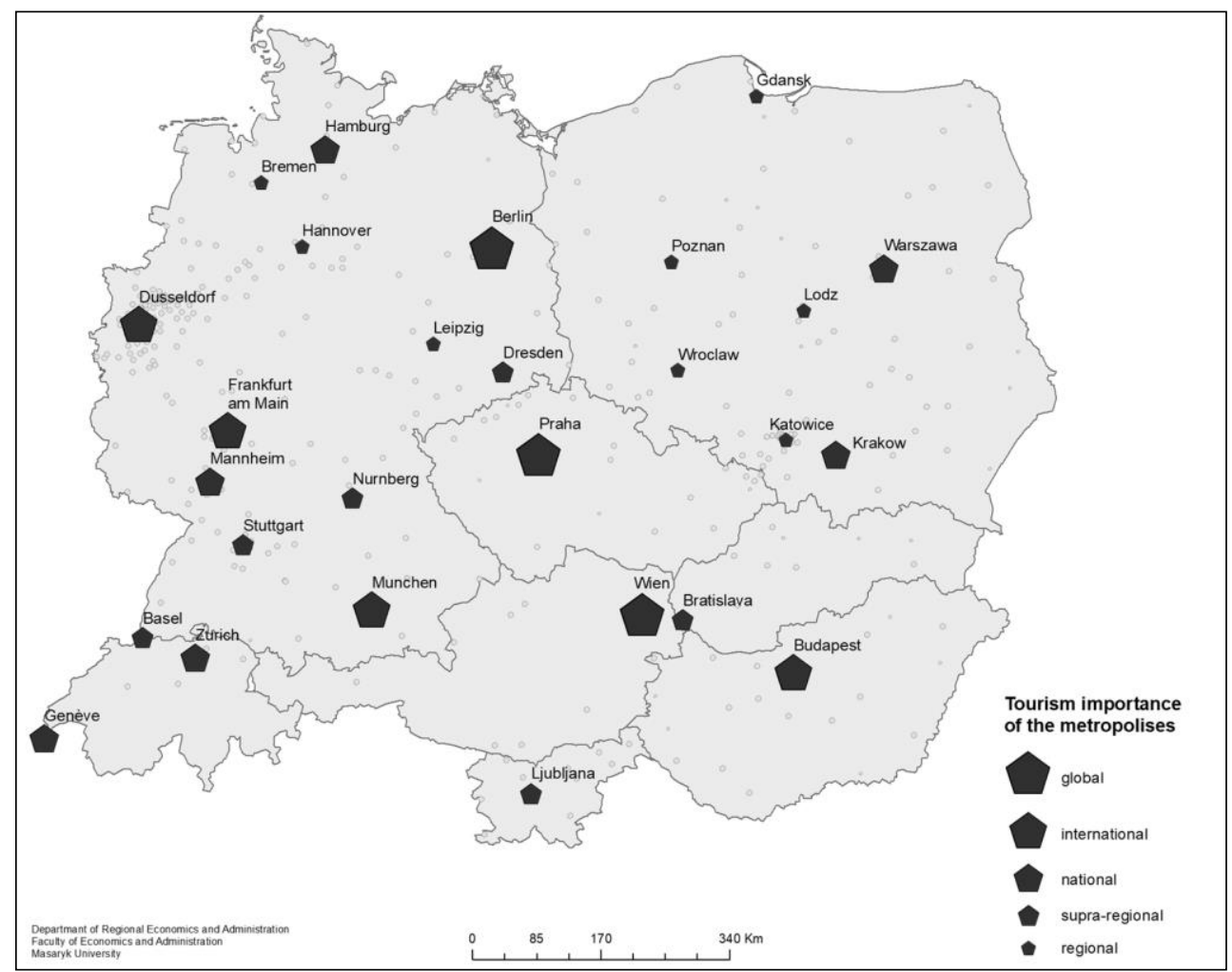

Fig. 1. Location of the study area (Source: TourMIS database, 2017; original work).

By application of a gravity model, we identified 261 tourist international flows; each flow includes a two-way stream of tourists. The overall volume of interactions reaches a value of 2.77 million visitors. A share of the Central European metropolises within the general performance of cities is only $7 \%$. On one hand, such a low share is determined by less than $1 / 3$ share of studied cities in the overall population of the Central European region. On the other hand, it indicates globality of the international tourism, whereas the most of performance is generated by the countries outside the Central European region. Above-average ties to the Central European region were found in Wroclaw (16\%), Poznan $(14 \%)$ and Bratislava (11\%). On the contrary, the weakest ties were found in Budapest and Krakow (Prague is slightly below the average).

On the basis of a geography analysis of individual tourist flows it can be concluded that the differences regarding their force are very significant. About half of their volume is generated by the first 24 interactions. In the layout of flows, strong ties between Germany, Austria and Switzerland (9 out of 15 most important ties fall upon the mentioned area) 
become evident. In this context, Vienna plays a fundamental role as the most important destination of all studied metropolises. The most important interaction whatsoever can be found between Vienna and Munich, followed by interlinking of Vienna and Berlin and other German cities (Hamburg, Rhein-Ruhr region, Frankfurt am M., etc.). Strong ties are also between Zurich and Munich and Berlin (see Table 1). High rate of interlinking of German-speaking countries is disrupted only by Prague and its ties to both Western and Eastern Europe, and by Budapest and its ties to Vienna and Berlin (Prague occupies the sixth position of the most visited European cities, and Budapest is included in the TOP 10).

With respect to the tourism, Poland is not linked much to other Central European countries. Warsaw, Wroclaw and Krakow have stronger ties, mainly to Germany. Despite clear attractiveness of Krakow, its periphery position prevents from having stronger position within the network of tourist flows. Its strongest tie to Berlin is as down as in the $62^{\text {nd }}$ position, and it ranks only fifth among Polish cities (behind Warsaw and Wroclaw).

Table 1.

Inbound and outbound tourism in the metropolises.

\begin{tabular}{|l|c|l|l|l|l|}
\hline & Inbound & Outbound & Total & $\begin{array}{l}\text { The main } \\
\text { sources of } \\
\text { inbound flows }\end{array}$ & $\begin{array}{l}\text { The main } \\
\text { destinations for } \\
\text { outbound flows }\end{array}$ \\
\hline Vienna & 620,774 & 424,522 & $1,045,296$ & $\begin{array}{l}\text { Munich, Rhine- } \\
\text { Ruhr, Berlin, } \\
\text { Frankfurt }\end{array}$ & $\begin{array}{l}\text { Munich, Berlin, } \\
\text { Prague, Hamburg }\end{array}$ \\
\hline Prague & 496,603 & 108,593 & 605,196 & $\begin{array}{l}\text { Berlin, Vienna, } \\
\text { Bratislava, Rhine- } \\
\text { Ruhr }\end{array}$ & $\begin{array}{l}\text { Bratislava, Vienna, } \\
\text { Budapest }\end{array}$ \\
\hline Zürich & 127,412 & 276,618 & 404,030 & $\begin{array}{l}\text { Rhine-Ruhr, } \\
\text { Munich, Stuttgart, } \\
\text { Vienna }\end{array}$ & $\begin{array}{l}\text { Munich, Berlin, } \\
\text { Vienna, Hamburg }\end{array}$ \\
\hline Berlin & 192,723 & 202,938 & 395,660 & $\begin{array}{l}\text { Vienna, Zürich, } \\
\text { Basel, Geneva }\end{array}$ & $\begin{array}{l}\text { Vienna, Prague, } \\
\text { Budapest, Wroclaw }\end{array}$ \\
\hline Munich & 188,239 & 197,304 & 385,542 & $\begin{array}{l}\text { Vienna, Zürich, } \\
\text { Basel, Geneva }\end{array}$ & $\begin{array}{l}\text { Vienna, Prague, } \\
\text { Zürich, Budapest }\end{array}$ \\
\hline $\begin{array}{l}\text { Rhine- } \\
\text { Ruhr }\end{array}$ & 104,634 & 219,517 & 324,151 & $\begin{array}{l}\text { Vienna, Zürich, } \\
\text { Basel, Geneva }\end{array}$ & $\begin{array}{l}\text { Vienna, Prague, } \\
\text { Zürich, Budapest }\end{array}$ \\
\hline Budapest & 185,105 & 96,307 & 281,412 & $\begin{array}{l}\text { Vienna, Berlin, } \\
\text { Rhine-Ruhr }\end{array}$ & $\begin{array}{l}\text { Vienna, Prague, } \\
\text { Munich, Krakow }\end{array}$ \\
\hline Basel & 58,036 & 161,698 & 219,734 & $\begin{array}{l}\text { Rhine-Ruhr, } \\
\text { Stuttgart, Munich, } \\
\text { Frankfurt am M. }\end{array}$ & $\begin{array}{l}\text { Berlin, Munich, } \\
\text { Vienna, Rhine-Ruhr }\end{array}$ \\
\hline Hamburg \\
Frankfurt
\end{tabular}

Source: original work 
The stated conclusions are well illustrated in the following graphic outcomes of network analysis by using the algorithm Geo Layout which is able to coordinate position of nodes within the network according to their latitude and longitude (Fig. 2). In this way visualisation of nodes and edges in real space was made possible. The colour of a node corresponds to a particular country, whereas thickness of the edge depends on the number of tourist arrivals.

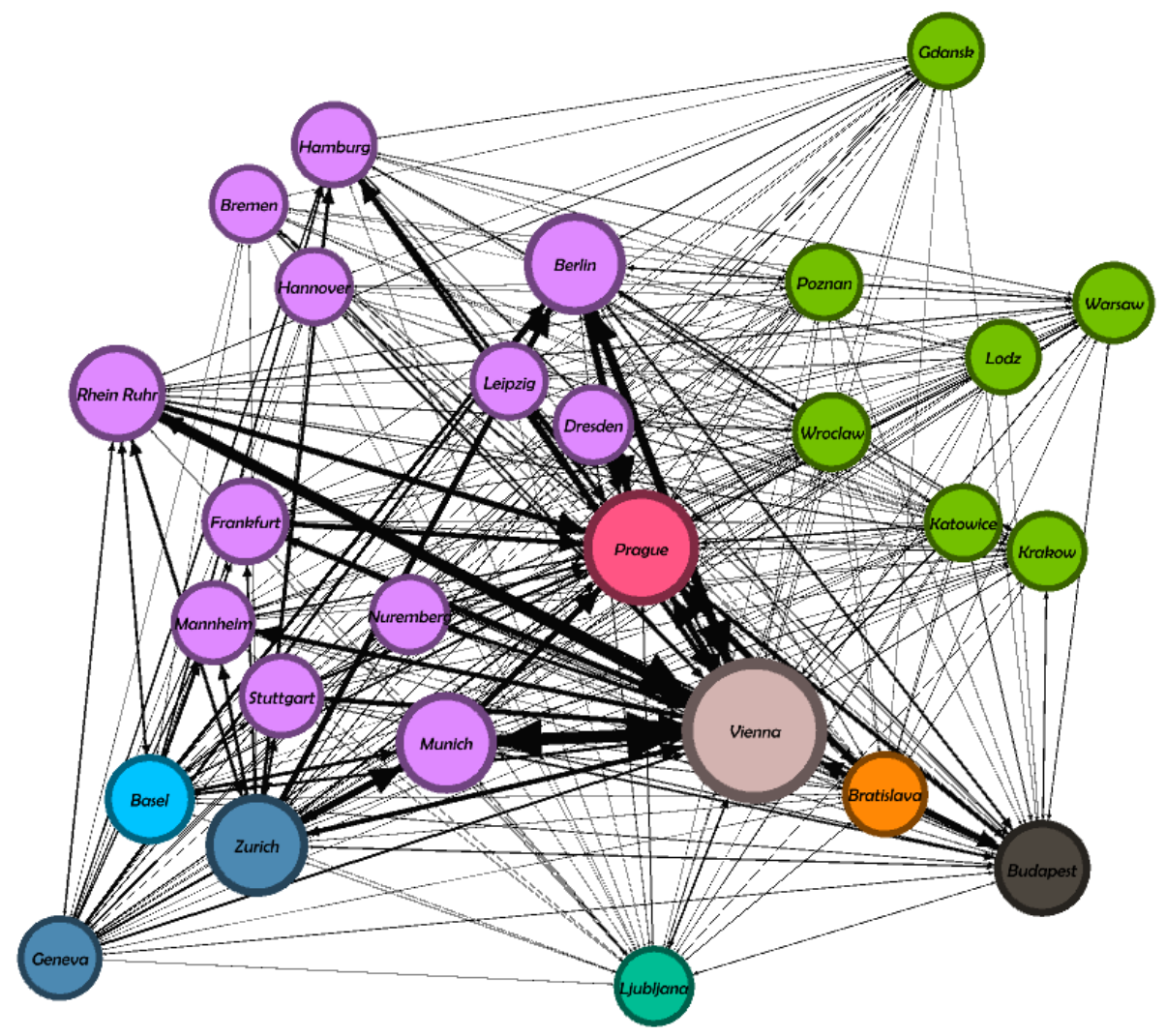

Fig. 2. Visualization of tourist flows in real space (Source: original work).

Within simulation, the network can be manipulated also by means of setting various filters. In this case, Fig. 3 includes only edges expressing more than 15,000 or alternatively more than 45,000 journeys. The other edges have been deleted. This procedure clearly indicates the importance of axis Hamburg - Berlin - Prague - Vienna - Bratislava Budapest, interlinking the North-western part of the region with the Eastern part. The second important metropolitan axis is Zurich - Munich - Vienna - Budapest, and last but not least, it is a tie between Rhein-Ruhr and Vienna, and then Prague, marginally. The picture shows that the flows are in the shape of a funnel, narrowing from the west towards the east. It means that despite a great number of the Western European metropolises the tourist flows go only to several selected metropolises in the Central and Eastern part of the region (Prague, Vienna, and Budapest). Moreover, this feature of spatial arrangement tends to grow stronger towards the Western part of the region. As a characteristic feature is the absence of ties to Polish cities and Ljubljana, Slovenia. 


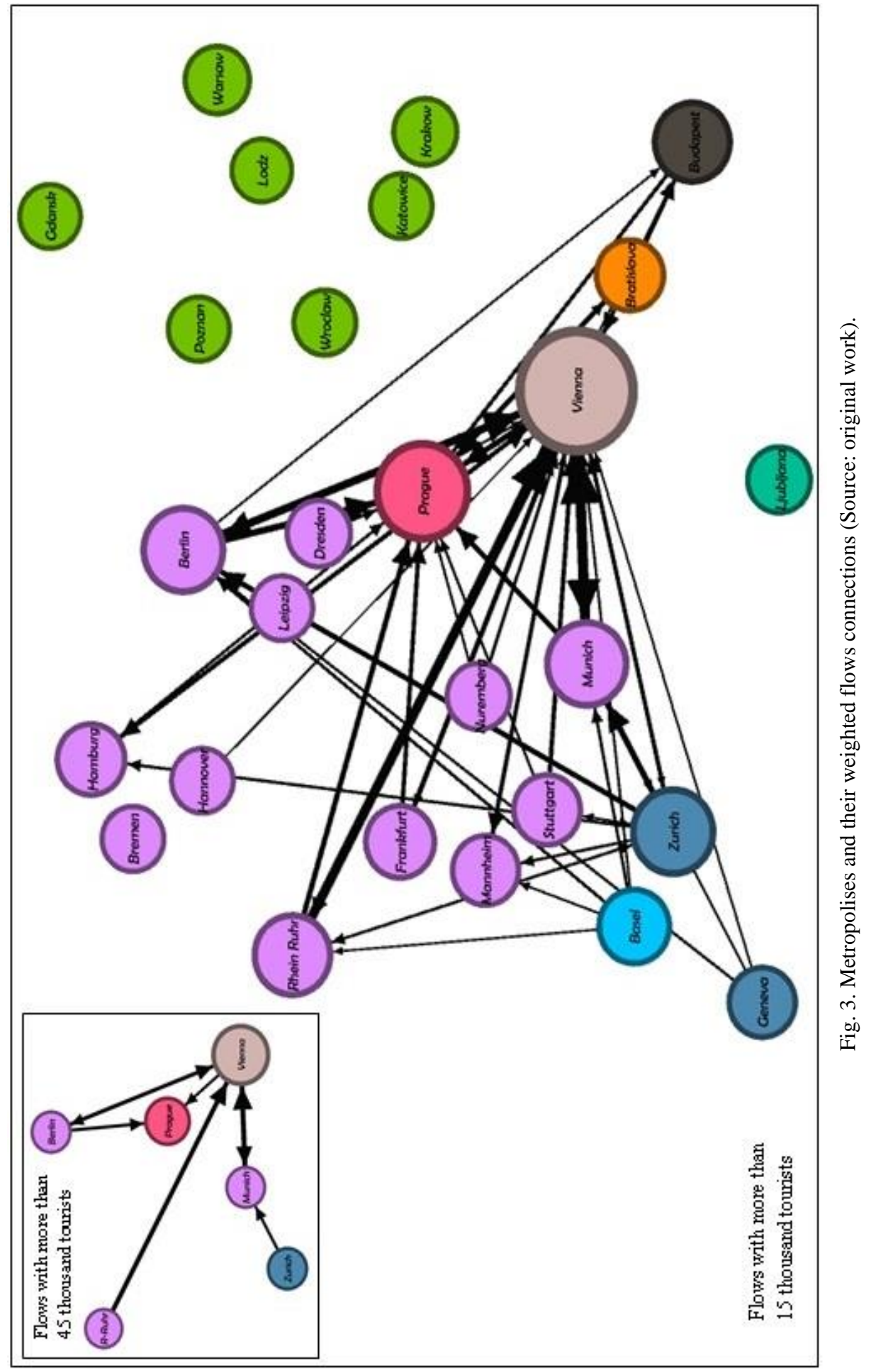


The central position within the network is occupied by Vienna. According to Table 2, Vienna achieved the highest values in all basic features of the network, whether it is the centrality degree (degree, in-degree, out-degree), closeness centrality, or betweenness centrality. These markers indicate not only the frequency and importance of Vienna being linked to the other metropolises, but also its position towards the others. Vienna represents some sort of a bridge between the Western and Eastern parts of the studied region (betweenness centrality is by $47 \%$ higher than Berlin, which ranks second).

Table 2.

Network metrices in analysed metropolises.

\begin{tabular}{|c|c|c|c|c|c|c|}
\hline Metropolises & State & In-degree & Out-degree & Degree & \begin{tabular}{|l|} 
Closeness \\
centrality \\
\end{tabular} & \begin{tabular}{|l|}
$\begin{array}{l}\text { Betweenness } \\
\text { centrality }\end{array}$ \\
\end{tabular} \\
\hline Vienna & AT & 25 & 21 & 46 & 0,83871 & 126,5635 \\
\hline Zurich & $\mathrm{CH}$ & 15 & 19 & 34 & 0,78788 & 50,44158 \\
\hline Prague & $\mathrm{CZ}$ & 26 & 16 & 42 & 0,72222 & 67,5744 \\
\hline Berlin & DE & 15 & 15 & 30 & 0,70270 & 86,29246 \\
\hline Budapest & $\mathrm{HU}$ & 24 & 15 & 39 & 0,70270 & 46,12996 \\
\hline Geneva & $\mathrm{CH}$ & 6 & 14 & 20 & 0,68421 & 7,298279 \\
\hline Basel & $\mathrm{CH}$ & 11 & 14 & 25 & 0,68421 & 22,88105 \\
\hline Rhein Ruhr & $\mathrm{DE}$ & 9 & 14 & 23 & 0,66667 & 21,47345 \\
\hline Munich & $\mathrm{DE}$ & 10 & 13 & 23 & 0,63415 & 15,99586 \\
\hline Frankfurt a. M. & $\mathrm{DE}$ & 7 & 13 & 20 & 0,63415 & 9,195914 \\
\hline Hamburg & $\mathrm{DE}$ & 6 & 11 & 17 & 0,60465 & 6,507387 \\
\hline Warsaw & PL & 14 & 8 & 22 & 0,59091 & 6,28049 \\
\hline Stuttgart & DE & 4 & 11 & 15 & 0,57778 & 1,710847 \\
\hline Katowice & $\mathrm{PL}$ & 2 & 7 & 9 & 0,57778 & 0,453968 \\
\hline Ljubljana & SLO & 9 & 7 & 16 & 0,57778 & 1,982782 \\
\hline Bratislava & SK & 13 & 6 & 19 & 0,56522 & 2,094234 \\
\hline Hannover & $\mathrm{DE}$ & 2 & 8 & 10 & 0,54167 & 0,385439 \\
\hline Nuremberg & $\mathrm{DE}$ & 6 & 8 & 14 & 0,54167 & 1,435536 \\
\hline Krakow & $\mathrm{PL}$ & 15 & 4 & 19 & 0,54167 & 2,83594 \\
\hline Poznan & PL & 5 & 4 & 9 & 0,54167 & 0,786429 \\
\hline Wroclaw & $\mathrm{PL}$ & 12 & 4 & 16 & 0,54167 & 2,83594 \\
\hline Bremen & $\mathrm{DE}$ & 2 & 7 & 9 & 0,53061 & 0,385439 \\
\hline Lodz & $\mathrm{PL}$ & 1 & 3 & 4 & 0,53061 & 0 \\
\hline Mannheim & DE & 6 & 5 & 11 & 0,50980 & 0,859274 \\
\hline Dresden & $\mathrm{DE}$ & 6 & 6 & 12 & 0,50980 & 0,736519 \\
\hline Leipzig & DE & 3 & 4 & 7 & 0,49057 & 0,076923 \\
\hline Gdansk & $\mathrm{PL}$ & 5 & 2 & 7 & 0,48148 & 0,786429 \\
\hline
\end{tabular}

Source: original work 
Concurrently, it is as strong as the pole which attracts the attendance also as a source of attendance for other metropolises. Zurich has a similar position, except for one difference it has significantly weaker betweenness markers. This is due to its crucial focus on Western metropolises in Germany and Austria. As for closeness centrality, the third position is occupied by Prague. Prague profits from its high attractiveness (as for arrivals, it is the second most visited city of all studied metropolises; it comes after Vienna); as a source destination for journeys to abroad it has weaker position. Therefore, it has been overtaken by Zurich. Another important metropolis within the network is Berlin which achieves, similarly as Vienna, high betweenness levels. Therefore, it can be regarded as an important transit hub. Moreover, it is necessary to mention Budapest which is well anchored within the network, despite its relatively peripheral location. In addition, the network analysis has proved a weak position of Polish cities, in particular, Lodge, Gdansk and Poznan.

Fig. 4 demonstrates differences in the layout of metropolises within the network with respect to outbound and inbound tourism. The outbound tourism is unambiguously affected by purchasing power, or alternatively, by differences in economic development of the studied metropolises. Tourist flows are dominated by Western Europe, with Vienna, Berlin, Munich, Rhein-Ruhr and Zurich in the lead. Typical feature of such countries is also high intensity of outbound tourism (the number of outbounds per capita) and strong mutual networking (German speaking countries). For instance, the intensity of outbounds performed by Vienna inhabitants is almost three times higher than in Prague. Polish cities achieve even lower outbound intensity level (one fifth of the Prague level).

The figure depicting inbound flows fundamentally affects the performance of Prague, as one of the most attractive destinations in Europe. Significantly weaker trend, but similar, can be seen in Budapest. On the other hand, the importance of Switzerland metropolises in inbound tourism is declining, which is due to the peripheral position of the region in connection to the studied area and price non-competitiveness for possible visitors coming from the countries of the Visegrad Group (V4).
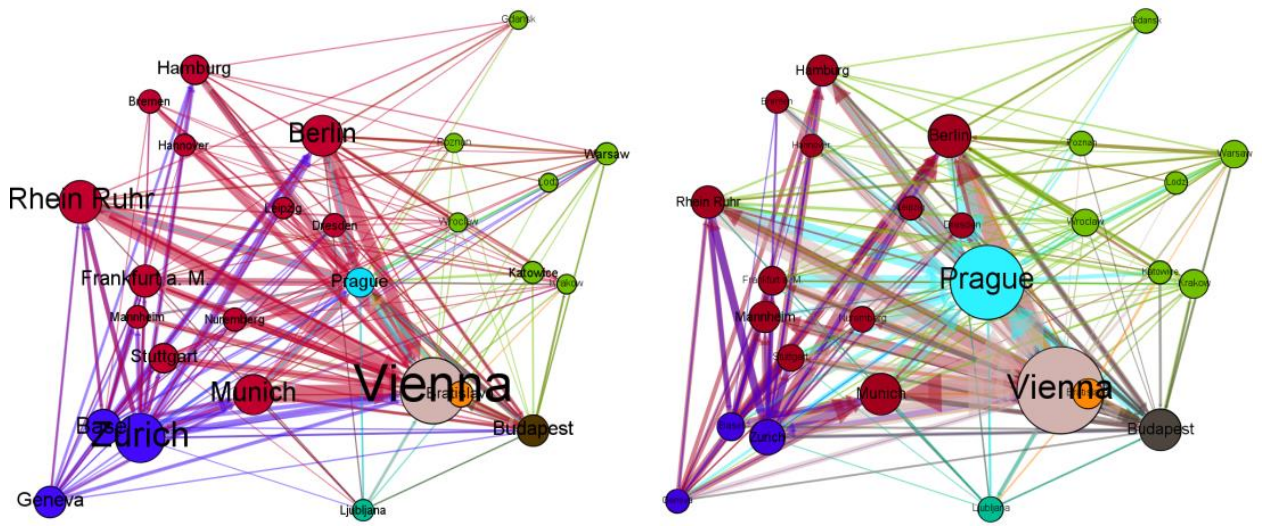

Fig. 4. Metropolises in the context of a) outbound and b) inbound tourism (Source: original work).

The last part of the tourist flows and their networks analysis is devoted to modelling of interactions by using force algorithm ForceAtlas 2, which helps to visualize the structural proximity within the network and thus, it shows the effect of forces on the nodes (Jacomy et al., 2014). Furthermore, the simulation includes the so-called modularity which clusters elements within the network and stipulates the level of separation of communities. If positive values are achieved, it indicates that community structures might be present 
(Newman, 2006). The extent of network structuration in a form of separation of communities may be highlighted on the basis of clusters distinguished by colours according to their modularity.

Application of algorithms generates two basic clusters, whereas the first one is created by metropolises from Germany, Austria and Switzerland, and the second one is focused rather to the East (mainly the V4 countries), provided that Budapest and Katowice tend to focus on the Western bloc. Yet, each of them has different reasons. As for the tourism, Katowice is not attractive, and its position is determined by force of outbounds to Germany and Austria. On the contrary, Budapest attracts attention of the Western European source markets. The third cluster is not complete, a dominating city is Berlin. In respect to modularity, the importance of Berlin for Polish cities is noticeable, and with respect to force algorithm, the results prove ambiguous position within the network divided between the above mentioned main clusters.

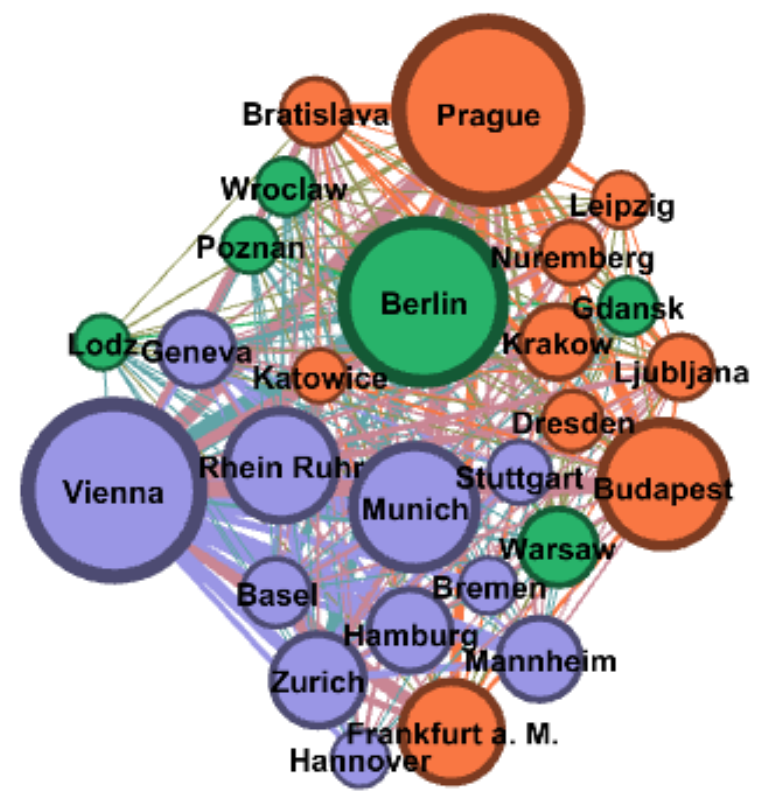

Fig. 5. Tourist flows in the context of structural proximity

(Source: original work).

\section{CONCLUSIONS}

Based upon results of the implemented analyses we can emphasize three conclusions, as follows. Firstly, spatial organization of tourism and its order structuration demonstrate rather small influence of the market proximity factor. The studied metropolises are not fundamentally integrated within Central Europe. This fact holds true especially for the most significant destinations such as Prague, Budapest or Berlin which are integrated within the network of global integrity. However, Vienna is an exception as it has strong ties both to the Central Europe area and the global area. Central European network of metropolises has somewhat significant influence on second cities (Šauer, 2016); which means, the cities operating mainly in the European market (Wroclaw, Bratislava or Poznan). 
Secondly, the analyses have revealed the fact that even after thirty years an imaginary boundary between Western and Eastern areas of the region has still been in existence. Probably, mental division of Europe into West and East is still persisting (e.g., Applebaum, 2017; Meinhof, 2018). This image is somewhat disrupted by Prague and Budapest that gradually constitute a new axis of Berlin - Prague - Vienna - Bratislava - Budapest. Polish cities remain outside the main flow. On one hand, they are challenged by German markets and V4 markets. In case of linking to V4 countries, higher degree of integration is limited by the quality and expansion of transport infrastructure, or by accessibility for remote source markets. On the other hand, their development might be successful due to the involvement into global processes. In reality, this approach is feasible only for Warsaw and Krakow.

The final conclusion is of methodological character. In respect to the tourist flows analysis, the network analysis is limited. High rate of interlinking (supported by using gravity model, the result of which is represented by ties of a n:n type) leads to a small differentiation of network matrices. This method is suitable, in particular, for the systems which are typical for larger diversity of behaviour of network elements, e.g. personal or other social networks.

\section{ACKNOWLEDGMENT}

This article was supported by the Ministry of Education, Youth and Sports of Czech Republic in the Operational Programme Research, Development and Education [grant "New mobility - high-speed transport systems and transport behaviour of the population" with project no. CZ.02.1.01/0.0/0.0/16_026/0008430].

\section{R E F E R E N C E S}

Applebaum, A. (2017) Between east and west: Across the borderlands of Europe. Anchor, Reprint edition. 336 p. ISBN 978-05-254-3318-7.

Bastian, M., Heymann, S. \& Jacomy, M. (2009) Gephi: an open source software for exploring and manipulating networks. ICWSM Conference, 8, 361-362.

Bobková, M. \& Holešinská, A. (2017) Networking in a destination from the perspective of virtual relationships and their spatial dimension. Geographia Technica, 12 (2), 10-19. ISSN 2065-4421. DOI: 10.21163/GT_2017.122.02.

Castells, M. (2008) The new public sphere: Global civil society, communication networks, and global governance. The Annals of the American Academy of Political and Social Science, 616 (1), 7893.

D'Agata, R., Gozzo, S. \& Tomaselli, V. (2013) Network analysis approach to map tourism mobility. Quality \& Quantity, 47 (6), 3167-3184.

Dumbrovská, V. \& Fialová, D. (2014) Tourist intensity in capital cities in Central Europe: Comparative analysis of tourism in Prague, Vienna and Budapest. Czech Journal of Tourism, 3 (1), 5-26.

Ferrante, M., Abbruzzo, A. \& De Cantis, S. (2017) Graphical models for estimating network determinants of multi-destination trips in Sicily. Tourism Management Perspectives, 22, 109119.

Flognfeldt, T. (1999) Traveler geographic origin and market segmentation: The multi trips destination case. Journal of Travel \& Tourism Marketing, 8 (1), 111-124.

Hanneman, R. A. \& Riddle, M. (2005) Introduction to social network methods. University of California, Riverside, California, $322 \mathrm{pp}$.

Hong, T., Ma, T. \& Huan, T. C. T. (2015) Network behavior as driving forces for tourism flows. Journal of Business Research, 68 (1), 146-156. 
Hoppe, B. \& Reinelt, C. (2010) Social network analysis and the evaluation of leadership networks. The Leadership Quarterly, 21 (4), 600-619. DOI: 10.1016/j.leaqua.2010.06.004.

IPK International. (2015) ITB World Travel Trends Report 2014/2015. Berlin: Messe Berlin GmbH.

Jacomy, M., Venturini, T., Heymann, S. \& Bastian, M. (2014) ForceAtlas2, a Continuous Graph Layout Algorithm for Handy Network Visualization Designed for the Gephi Software. PLoS ONE, 9 (6). DOI: 10.1371/journal.pone.0098679.

Jałowiecki, B. (2006) Polish cities and metropolisation processes. Studia Regionalne i Lokalne, 7584. ISSN 1509-4995.

Khadaroo, J. \& Seetanah, B. (2008) The role of transport infrastructure in international tourism development: A gravity model approach. Tourism Management, 29 (5), 831-840.

Lee, S. H., Choi, J. Y., Yoo, S. H. \& Oh, Y. G. (2013) Evaluating spatial centrality for integrated tourism management in rural areas using GIS and network analysis. Tourism Management, 34, 14-24. ISSN 0261-5177. DOI: 10.1016/j.tourman.2012.03.005.

Lew, A. A. \& McKercher, B. (2002) Trip destinations, gateways and itineraries: The example of Hong Kong. Tourism Management, 23 (6), 609-621.

Lue, C. C., Crompton, J. L. \& Fesenmaier, D. R. (1993) Conceptualization of multi-destination pleasure trips. Annals of Tourism Research, 20 (2), 289-301.

Luo, W. \& MacEachren, A. M. (2014) Geo-social visual analytics. Journal of Spatial Information Science, 8, 27-66.

McKercher, B. \& Lew, A. A. (2004) Tourist flows and the spatial distribution of tourists. A Companion to Tourism, 36-48.

McKercher, B., Shoval, N., Ng, E. \& Birenboim, A. (2012) First and repeat visitor behaviour: GPS tracking and GIS analysis in Hong Kong. Tourism Geographies, 14 (1), 147-161.

Meinhof, U. H. (2018) Living (with) Borders: Identity Discourses on East-West Borders in Europe: Identity Discourses on East-West Borders in Europe. Routledge, Reprint edition. 162 p. ISBN 978-13-517-4788-2.

Mings, R. C., \& McHugh, K. E. (1992) The spatial configuration of travel to Yellowstone National Park. Journal of Travel Research, 30 (4), 38-46.

Newman, M. E. (2006) Modularity and community structure in networks. Proceedings of the National Academy of Sciences, 103 (23), 8577-8582.

Pařil, V., Kunc, J., Šašinka, P., Tonev, P. \& Viturka, M. (2015) Agglomeration effects of the Brno city (Czech Republic) as exemplified by the population labour mobility. Geographia Technica, 10 (1).

Shoval, N. \& Isaacson, M. (2007) Sequence alignment as a method for human activity analysis in space and time. Annals of the Association of American Geographers, 97 (2), 282-297.

Šauer, Martin. (2016). V4 second cities as a tourist destination - a view of students selected Brno universities. In Klímová, V.; Žítek, V. (Eds.). XIX. International Colloquium on Regional Sciences. Paper Proceedings. Brno: Masaryk University, 2016. 977-983, ISBN 978-80-2108273-1. DOI: 10.5817/CZ.MUNI.P210-8273-2016-126.

TourMIS database. (2017) Marketing-Information-System for tourism managers. Wien: MODUL University Vienna. Available online: wwww.tourmis.info (downloaded 30th June 2017).

UN Habitat. (2015) The State of Asian and Pacific Cities 2015 - Urban transformations Shifting from quantity to quality. The United Nations Economic and Social Commission for Asia and the Pacific (ESCAP) and United Nations Human Settlements Programme (UN-Habitat). ISBN: (Volume) 978-92-1-132681-9

UNWTO. (2018) UNWTO/WTCF City Tourism Performance Research. Madrid: UNWTO. ISBN 978-92-844-1961-6.

UNWTO. (2017) Tourism Highlights. Madrid: UNWTO, 2017 Edition. ISBN 978-92-844-1901-2.

Viturka, M., Pařil, V., Tonev, P., Šašinka, P. \& Kunc, J. (2017) The Metropolisation Processes - A Case of Central Europe and the Czech Republic. Prague Economic Papers, Praha: University of Economics, 26 (5), 505-522. ISSN 2336-730X. DOI: 10.18267/j.pep.624.

Wöber, K. W. (2003) Information supply in tourism management by marketing decision support systems. Tourism Management, 24 (3), 241-255. 